\title{
CFD Analysis of Box Wing Configuration
}

\author{
Sahana D S ${ }^{1}$, Abdul Aabid ${ }^{2}$ \\ Assistant Professor, Dept. of Aeronautical Engineering, Mangalore Institute of Technology and Engineering, Badaga-Mijar, Moodabidri, \\ Mangalore, D.K.-574225, India
}

Assistant Professor, Dept. of Aeronautical Engineering, Mangalore Institute of Technology and Engineering, Badaga-Mijar, Moodabidri, Mangalore, D.K.-574225, India

\begin{abstract}
Box wing configuration is an unconventional non planar configuration comparable to a conventional wing whose wings are connected on the tips by vertical winglets. In this way the wing configuration forms a rectangular box in the front view. The box wing configuration allows for savings in induced drag which results in reduced fuel consumption. To understand the basic aerodynamic features and their influence on box wing aerodynamics, CFD analysis is carried out based on various design parameters like height to span ratio and cant angle of box wing for optimum induced drag using ICEM CFD and ANSYS CFX solver. The design mission and geometry constraints of the reference aircraft are applied to the box wing aircraft so that performance and operational characteristics of both aircraft can be compared.
\end{abstract}

Keywords: ICEM CFD, ANSYS CFX.

\section{Introduction}

Drag reduction results in a direct decrease in operating costs and in an in-direct decrease in noise and emissions levels. Drag during the cruise phase of large transport aircraft consist of friction and induced drag, where the induced drag is relatively lower than the friction drag. But still it consists of $43 \%$ of the total drag budget (Frediani, 2006). Thus, any reduction in the induced drag will directly improve the efficiency of the overall design. Moreover induced drag is also coupled with viscous or friction drag (Kroo I.-2005), thus its reduction can be beneficial in a greater extent than actually comprehended.

Thus, this study is primarily based on finding an insight into the unique aerodynamic characteristics of box-wing configurations, with aims to outline and capture the important factors of the design for drag reduction which can consequently lead to performance improvements.

\section{Literature Review}

Next to these theoretical investigations some design studies have been performed as well. The first important to mention is Lockheed 1974 which gives a good summary of the practical aspects of box wing aerodynamics as well as to stability and controllability, together with a description of the design synthesis of a long range aircraft. In this study it was found that box wing aircraft are very sensitive to flutter. This sensitivity seems to get stronger with an increasing $h / b$ ratio.

One of the starting points of the current thesis is Khan 2010 which presents results of preliminary aerodynamic investigations of the box wing configuration conducted with the help of low fidelity CFD methods [1].

Kroo 2005 gives a good summary concerning non planar configurations. There it is mentioned that the reduction of induced drag not only affects the fuel consumption during cruise, but rather all flight phases. The reason is that the aircraft has a significantly improved climb performance as well, because acc. to Kroo 2005 the induced drag makes out 80 to $90 \%$ of the total drag during takeoff and initial climb [2-5].

Initial examinations were already performed in the twenties of the twentieth century by Ludwig Prandtl (Prandtl 1924) presenting a theory for assessing the induced drag of multi planes. Further theoretical aspects of box wing aerodynamics were presented in Durand 1935 which base on investigations conducted by Ludwig Prandtl, Theodore von Kármán and Max Munk. DeYoung 1980 uses their findings to conduct a summary about the span efficiency factor of non-planar wing configurations. Cahill 1954 gives the results of wind tunnel tests with a simple box wing like configuration [6].

For a huge part, more recent studies have been conducted at the University of Pisa under the supervision of Prof. Aldo Frediani (Frediani 2005, Frediani 2007, and Frediani 2009). They give a survey of some of the design challenges and approaches of how to cope with them and contain examinations of medium and long range aircraft as well as ULM aircraft [7].

One of these is the box wing configuration, a biplane with vertically and horizontally staggered wings whose tips are connected by extended winglets. The most recognized benefits of this configuration are its low induced drag and alleged structural superiority

\section{Problem Definition}

\subsection{Selecting a Base Design}

The reference variables like design lift coefficient, operating Mach number and other reference values of an Airbus A320 was chosen as the baseline aircraft. Typical values used during the analysis are shown in table 3.1 below (Jane's all the world aircraft, 2009). 


\section{International Journal of Science and Research (IJSR) \\ ISSN (Online): 2319-7064}

Index Copernicus Value (2013): 6.14 | Impact Factor (2015): 6.391

Table 1: Reference data from A320

\begin{tabular}{|c|c|c|c|}
\hline Specification & Notation & Value & Units \\
\hline Wing Reference Area & Sref & 122.4 & $\mathrm{~m}^{2}$ \\
\hline Span & $b$ & 34.1 & $\mathrm{~m}$ \\
\hline Aspect Ratio & $A R$ & 9.5 & - \\
\hline Wing Quarter Chord Sweep & $\Lambda c / 4$ & 25 & $\circ$ \\
\hline Taper Ratio & $\lambda$ & 0.24 & - \\
\hline Root Chord & $c_{r}$ & 6.10 & $\mathrm{~m}$ \\
\hline Mean Aerodynamic Chord & $M A C$ & 4.29 & $\mathrm{~m}$ \\
\hline Weight - Empty & $W_{e}$ & 42100 & $\mathrm{Kg}$ \\
\hline Weight - Maximum take-off & $W M T O W$ & 77000 & $\mathrm{Kg}$ \\
\hline Cruise Mach No. & $M c r$ & 0.78 & - \\
\hline
\end{tabular}

Table 2: Box wing data

\begin{tabular}{|cccc|}
\hline Parameter & $\begin{array}{c}\text { Forward } \\
\text { wing }\end{array}$ & Aft wing & $\begin{array}{c}\text { Reference } \\
\text { wing }\end{array}$ \\
\hline Span $[\mathrm{m}]$ & 34 & 34 & 34 \\
Reference Area $\left[\mathrm{m}^{2}\right]$ & 61 & 61 & 122 \\
Aspect ratio & 18,9 & 18,9 & 9,45 \\
Root chord length $[\mathrm{m}]$ & 2,9 & 2 & 5,9 \\
Taper ratio & 0,24 & 0,8 & 0,24 \\
Sweep (1/4 chord) & $28,5^{\circ}$ & $-28^{\circ}$ & $25^{\circ}$ \\
Dhedral & $6^{\circ}$ & $0^{\circ}$ & $6^{\circ}$ \\
\hline
\end{tabular}

Present CFD analysis is carried out in ANSYS CFX. Boundary conditions are defined in CFX pre and CFX solver runs the solution and results are tabulated from CFD POST.

Analysis is carried at following cases:

Table 3: Cases of CFD Analysis

\begin{tabular}{|c|c|c|c|c|}
\hline S. No & $\begin{array}{c}\text { Mach } \\
\text { Number }\end{array}$ & Angle of attack & h/b ratio & Cant angle \\
\hline 1 & 0.73 & $5^{0}, 10^{0}$ and $15^{0}$ & $1 \& 0.75$ & $0^{0}, 5^{0}, 10^{0}$ \\
\hline 2 & 0.78 & $5^{0}, 10^{0}$ and $15^{0}$ & $1 \& 0.75$ & $0^{0}, 5^{0}, 10^{0}$ \\
\hline 3 & 0.85 & $5^{0}, 10^{0}$ and $15^{0}$ & $1 \& 0.75$ & $0^{0}, 5^{0}, 10^{0}$ \\
\hline
\end{tabular}

As non-planar configurations have fundamentally different design variables from conventional designs, the design approach for the following work is to first outline the basics of box-wing design and elaborates its design drivers. The goal is to investigate possible design issues of box-wing configurations.

\section{Validation}

To validate the CFD methodology present results are compared with paper results published by F.A Khan. The Mach contour results in below figures 5.5 and 5.6 are for 0.78 Mach at zero degrees angle of attack. So, validation is done with respect to same conditions for base wing and box wing for 0.75 height to span $(\mathrm{h} / \mathrm{b})$ ratio

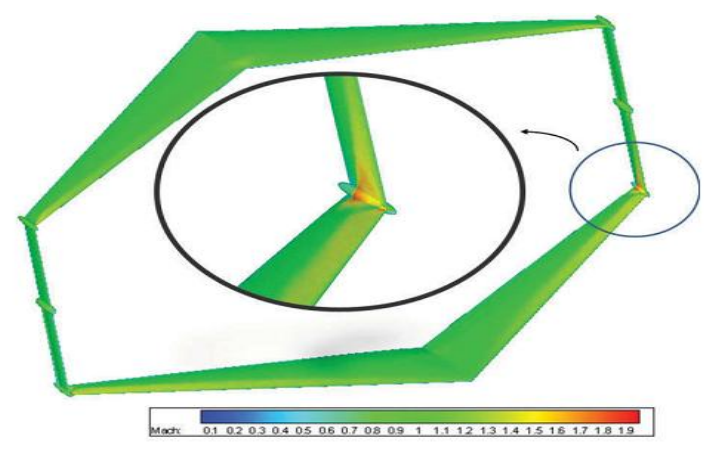

Figure 2: Mach contour of Box wing

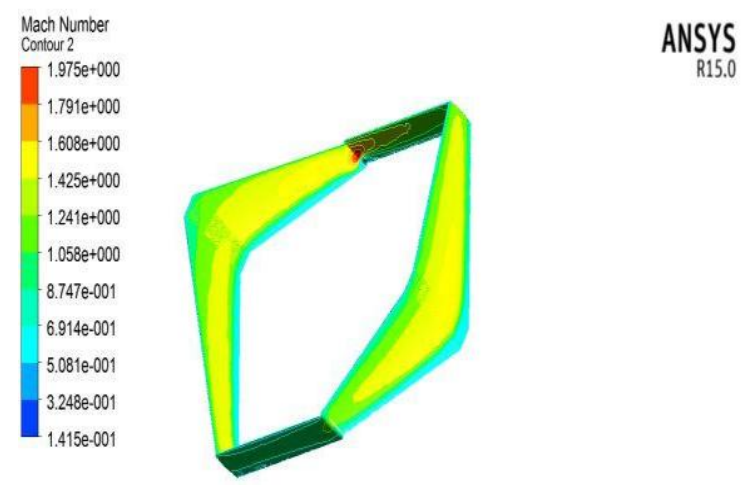

Figure 3: Mach contour of Box wing

\section{Results and Discussions}

\subsection{Box Wing at $M=0.78$}

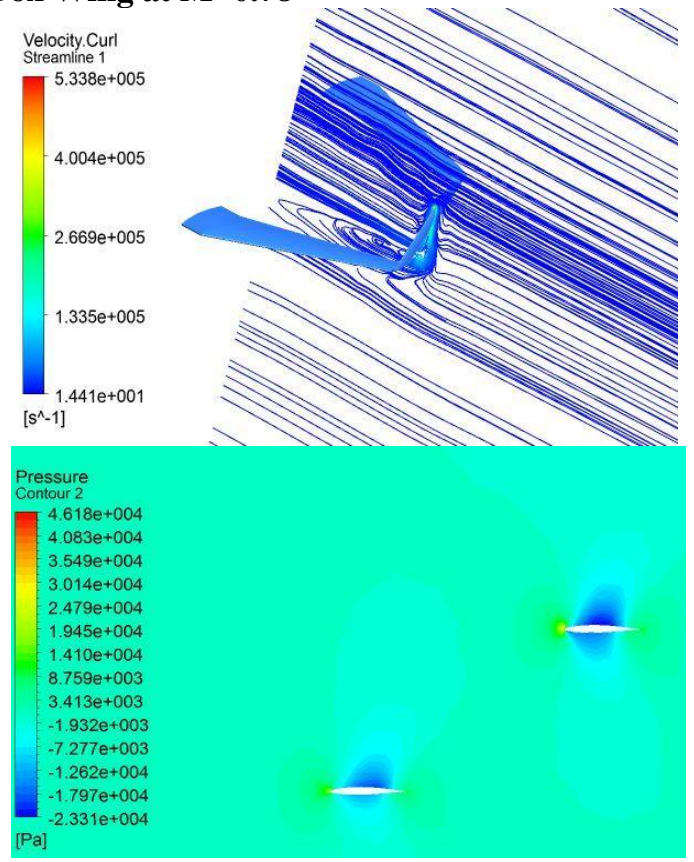

Figure 4: Velocity streamlines and Pressure counter of box wing at $\mathrm{M}=0.78 \mathrm{AT} 15^{\circ} \mathrm{AOA}$ for $\mathrm{h} / \mathrm{b}=1$ 


\section{International Journal of Science and Research (IJSR) \\ ISSN (Online): 2319-7064}

Index Copernicus Value (2013): 6.14 | Impact Factor (2015): 6.391

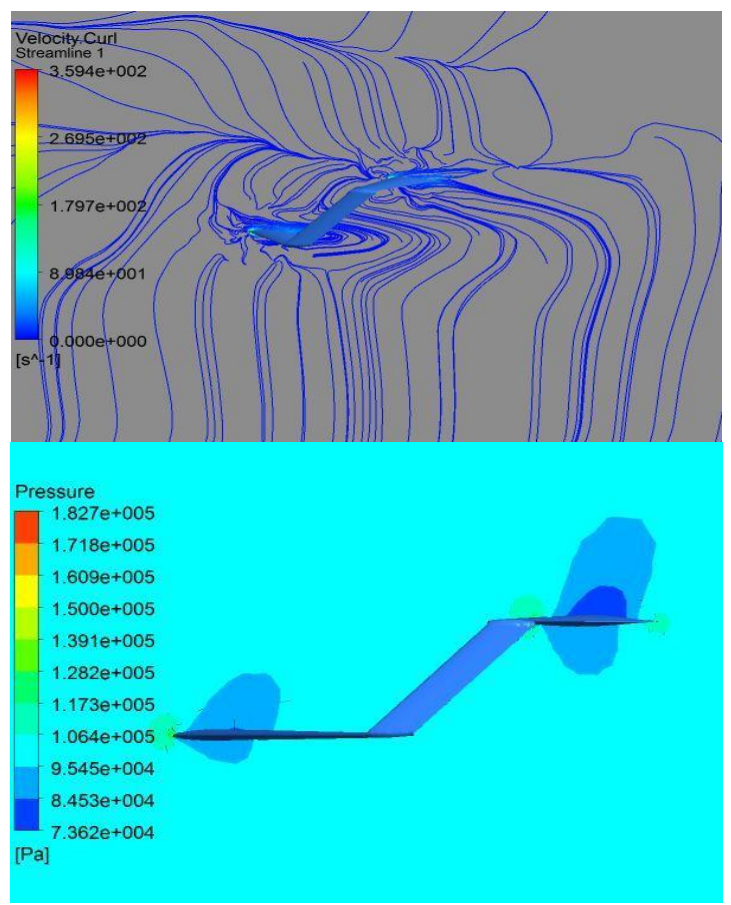

Figure 5: Velocity streamlines and Pressure counter of box wing at $\mathrm{M}=0.78 \mathrm{AT} 15^{0} \mathrm{AOA}$ for $\mathrm{h} / \mathrm{b}=0.75$

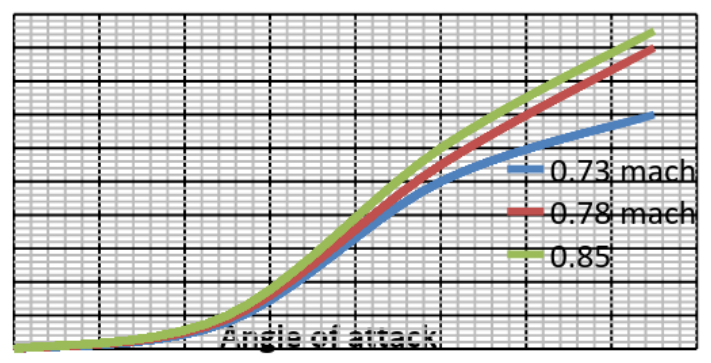

Figure 6: Variation of coefficient drag v/s AOA of box wing for $\mathrm{h} / \mathrm{b}=1$

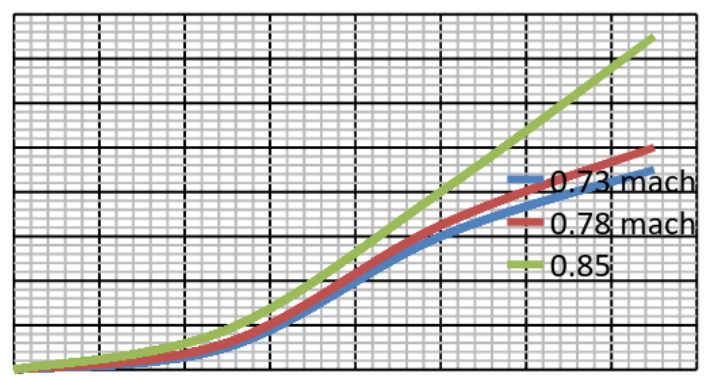

Figure 7: Variation of coefficient drag v/s AOA of box wing for $\mathrm{h} / \mathrm{b}=0.75$

From the above graphs coefficient of drag is more $\mathrm{h} / \mathrm{b}=$ 0.75 because of intereference effect. Height to span ratio variation is the most important design variable for a boxwing aircraft. Here the general trend can be understood as that when a single wing is divided into two wings having the same total area and span as the original wing, maximum induced drag reduction is achieved (Raymer, 1992). In other words aspect ratio has been doubled and as per basic aerodynamics an increase in aspect ratio reduces the in induced drag.

\subsection{Box Wing Varying Cant Angle}

Cant angle is defined as the mounting angle of the winglet with respect to the main wing. When it is positive (winglet tilted out), it is adding up to the total span of the wing. Thus it is expected to produce an induced drag reduction as effective span is increasing.

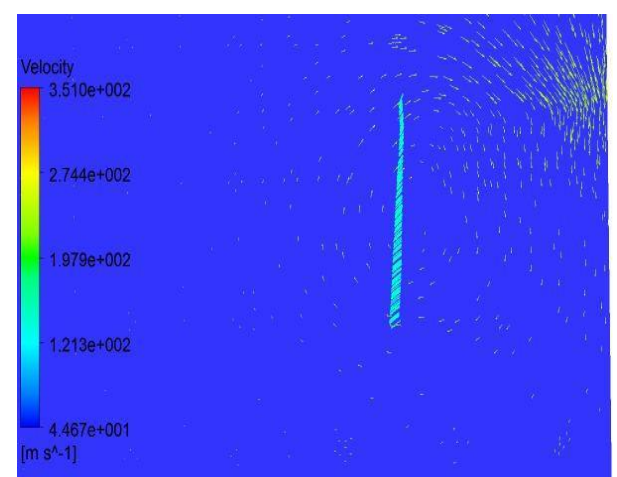

Figure 8: Velocity vectors of box wing at $\mathrm{M}=0.73,5^{0} \mathrm{AOA}$ and $5^{\circ}$ cant angle

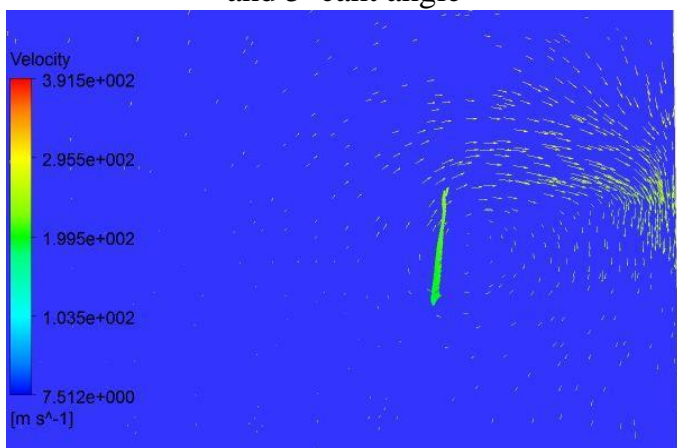

Figure 9: Velocity vectors of box wing at $\mathrm{M}=0.73,5^{0} \mathrm{AOA}$ and $10^{\circ}$ cant angle

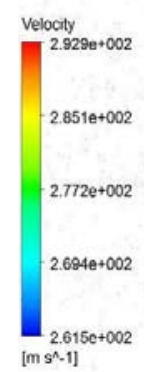

Figure 10: Velocity vectors of box wing at $\mathrm{M}=0.73,10^{\circ}$ AOA and $5^{\circ}$ cant angle

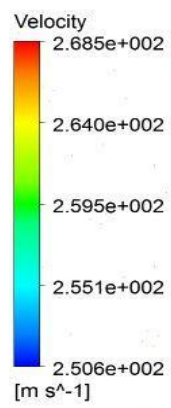

Figure 11: Velocity vectors of box wing at $M=0.73,10^{\circ}$ Mach $=0.73$ at $15^{\circ} \mathrm{AOA}$

\section{Volume 5 Issue 4, April 2016}




\section{International Journal of Science and Research (IJSR) ISSN (Online): 2319-7064}

Index Copernicus Value (2013): 6.14 | Impact Factor (2015): 6.391

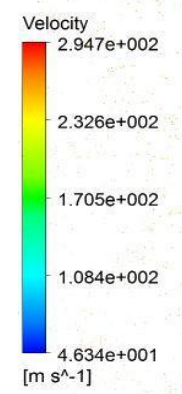

Figure 12: Velocity vectors of box wing at $M=0.73,15^{0}$ AOA and $5^{\circ}$ cant angle

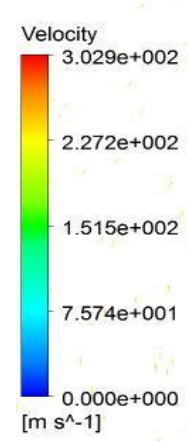

Figure 13: Velocity vectors of box wing at $\mathrm{M}=0.73,15^{0}$ AOA and $10^{\circ}$ cant angle

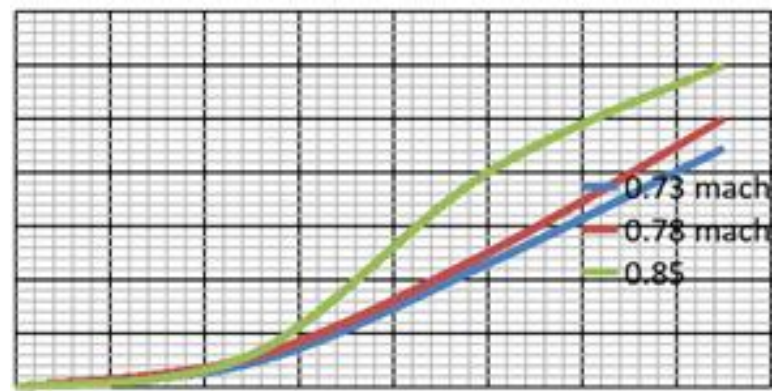

Figure 14: Variation of coefficient drag v/s AOA of box wing for cant angle $5^{0}$

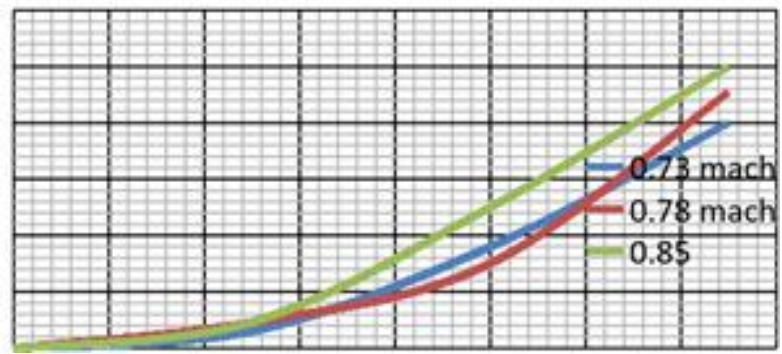

Figure 15: Variation of coefficient drag v/s AOA of box wing for cant angle $10^{\circ}$

Above Figures shows the variation of drag with respect to angle of attack for a particular cant angle for a box-wing configuration. This cant variation affects the strength of vortices which creates induced drag. In normal wings winglets are used to reduce induced drag i.e increasing aspect ratio. As the aspect ratio increases the difference of pressure on wing surfaces decreases due to which the formation of vortices is reduced.

From above results it can be seen in every case the maximum velocity is high for $5^{0}$ Cant angle than for $10^{\circ}$ because the more increase in cant angle effects the flow development along the wing minimizing pressure difference and curl of velocity i.e formation of vortices, downward velocity and induced drag. But as the angle of attack is increased the effect of cant angle is reduced because of flow separation i.e. adverse pressure gradient.

\section{Conclusion}

For the analysis of non-planar systems, ANSYS CFD software can be utilized. Here two important conclusions can be drawn from this work. First, appropriate grid should be established and maintained throughout the analysis. Secondly, during this analysis care must be taken while defining boundary conditions and turbulence model. If not defined properly, it may result in wrong values and lead to incorrect conclusions afterwards.

Furthermore, height to span ratio is the most important variable which directly influences the overall efficiency. Further improvement can be made by adjusting the cant angles for winglets. From the present analysis, it can be concluded with $\mathrm{h} / \mathrm{b}=1$ and cant angle $10^{\circ}$ has given optimum induced drag for various flight conditions.

\section{References}

[1] F.A Khan, P. Krammer, D. Scho-lz, "Preliminary Aerodynamic Investigation of Box-Wing Configurations using Low Fidekity Codes," at Deutscher Luft- und Ramfahrtkongress 2010.

[2] Kroo, I. (2006), "Aircraft Design: Synthesis and Analysis," Desktop Aeronautics, Inc. (http://adg.stanford.edu/aa241/welcome.html).

[3] Kroo, I. (2000), "Design and development of the SWIFT: a foot-launched sailplane," at AIAA-00-4336.

[4] Kroo, I. (2001), "Drag Due to Lift: Concepts for Prediction and Reduction. Annual Review Fluid Mechanics," pp.587-617.

[5] Kroo, I. (2005), "Non planar Wing Concepts for Increased Aircraft Efficiency," VKI lecture series on Innovative Configurations and Advanced Concepts for Future Civil Aircraft.

[6] Munk, M. (1921), "The Minimum Induced Drag of Airfoils," NACA Rep.121.

[7] Frediani, e. a. (2005), "A 250 Passenger Prandtl Plane Transport Aircraft" XVIII CONGRESSO NAZIONALE AIDAA.

\section{Author Profile}

Ms. Sahana D.S received the BE degree in Aeronautical Engineering from KBNCE in 2012 and M-Tech degree in Aerospace Engineering from MRCET in 2015. Currently working as an Assistant Professor in MITE.

Mr. Abdul Aabid received the BE degree in Aeronautical Engineering from KBNCE in 2010 and M-Tech degree in Aerospace Engineering from MRCET in 2014. Currently working as an Assistant Professor in MITE. Total Have a four year teaching experience. During teaching guided six projects for undergraduate students. 